\title{
Establishment of perennial forages intercropped with soybean for integrated crop-livestock systems
}

\author{
Luís Armando Zago Machado(1), Ulysses Cecato(2), Eder Comunello(1), Germani Concenço(3) and Gessi Ceccon ${ }^{(1)}$ \\ (1)Embrapa Agropecuária Oeste, BR 163, Km 253, CEP 79804-970 Dourados, MS, Brazil. E-mail: luis.zago@embrapa.br, \\ eder.comunello@embrapa.br, gessi.ceccon@embrapa.br (2)Universidade Estadual de Maringá, Avenida Colombo, no 5.790, Jardim \\ Universitário, CEP 87020-900 Maringá, PR, Brazil. E-mail: ulyssescecato@gmail.com ${ }^{(3)}$ Embrapa Clima Temperado, Rodovia BR-392, \\ Km 78, $9^{\circ}$ Distrito, Monte Bonito, Caixa Postal 321, CEP 96010-971 Pelotas, RS, Brazil. E-mail: germani.concenco@embrapa.br
}

\begin{abstract}
The objective of this work was to evaluate soybean (Glycine max) grain yield and the establishment of perennial intercropped forages. Soybean was evaluated in sole crop and intercropped with the following forages: Megathyrsus maximus, Aruana and BRS Tamani cultivars; Urochloa brizantha, Xaraés, BRS Piatã, and BRS Paiaguás cultivars; U. decumbens; and U. ruziziensis. A randomized complete block design was used, with seven replicates, in the 2011/2012 and 2012/2013 crop seasons. In the intercropped system, the forages were sown 21 and 14 days after soybean emergence, in the first and second crop seasons, respectively. Grain yield did not differ for soybean in sole crop or intercropped, except for soybean + U. ruziziensis and soybean + 'BRS Paiaguás', which were less productive in the second year of evaluation. The 'BRS Tamani' forage was the most suited for intercropping with soybean, considering its morphological characteristics and its low competition potential. Soybean intercropped with perennial forages contributes to suppress weed growth and, overall, does not compromise soybean yield.
\end{abstract}

Index terms: Brachiaria, Megathyrsus, Panicum, Urochloa, crop-livestock integration, weed interference.

\section{Estabelecimento de forrageiras perenes em consórcio com soja, para sistemas integrados de produção agropecuária}

\begin{abstract}
Resumo - O objetivo deste trabalho foi avaliar a produção de grãos de soja (Glycine max) e o estabelecimento de forrageiras perenes, em cultivo consorciado. A soja foi avaliada em cultivo solteiro e consorciada com os capins: Megathyrsus maximus, cultivares Aruana e BRS Tamani; Urochloa brizantha, cultivares Xaraés, BRS Piatã e BRS Paiaguás; U. decumbens; e U. ruziziensis. Utilizou-se o delineamento experimental de blocos ao acaso, com sete repetições, nas safras de 2011/2012 e 2012/2013. No cultivo consorciado, as forrageiras foram semeadas 21 e 14 dias após a emergência da soja, na primeira e na segunda safra, respectivamente. $\mathrm{O}$ rendimento de grãos da soja solteira e o da consorciada não diferiram, exceto nos cultivos soja + U. ruziziensis e soja + 'BRS Paiaguás', que apresentaram menor rendimento no segundo ano de avaliação. O capim 'BRS Tamani' foi o mais adequado para estabelecimento em consórcio com a soja, ao se considerar suas características morfológicas e seu baixo potencial de competição. O consórcio de soja e forrageiras perenes contribui para supressão do crescimento de plantas daninhas e, de maneira geral, não compromete o rendimento da soja.
\end{abstract}

Termos para indexação: Brachiaria, Megathyrsus, Panicum, Urochloa, integração lavoura-pecuária, matocompetição.

\section{Introduction}

Specialized production systems are vulnerable to market volatilities (Campos, 2007) and to climatic instabilities (Pinto et al., 2013), and are often associated with soil and pasture degradation. Integrated crop-livestock systems (ICLS) are an alternative to specialization because they promote crop diversification (Vilela et al., 2011) and rotation, being commonly linked to the recovery of soil structure and to the reduction in the seasonality of forage production (Vilela et al., 2011).

Forage availability can be increased by intercropping forages with annual crops (Vilela et al., 2011). This intercrop is feasible because the initial growth rate of perennial forages is lower than that of annual crops and, therefore, they represent a low risk to grain yield (Cobucci \& Portela, 2003). The intercropping of corn and palisade grass is used in pasture recovery; however, the establishment of forages intercropped 
with soybean is still a challenge, given the small size and the low competition capacity of the oilseed (Kluthcouski \& Aidar, 2003). The competition of grasses in intercropping can be minimized by delayed planting and by using forage (Duarte et al., 1995) and soybean (Crusciol et al., 2012) cultivars suitable for intercropping. However, studies on these cultivation modalities are still insufficient for an effective recommendation (Vilela et al., 2011), which, if viable, will favor an increase in productivity without the need for area expansion (Crusciol et al., 2014).

The forages currently available for intercropping were not improved specifically for ICLS and normally present limited use for both crop rotation and croplivestock integration. Some recently introduced cultivars have characteristics that are more favorable to this type of crop, due to their greater productivity and ease in handling regarding animals and herbicides (Machado \& Valle, 2011). However, phytotechnical adjustments are still necessary for the efficient establishment of forages in intercropping, especially with soybean.

The objective of this work was to evaluate soybean grain yield and the establishment of perennial intercropped forages.

\section{Materials and Methods}

The study was conducted in the municipality of Dourados, in the state of Mato Grosso do Sul, Brazil. The climate of the region is of the Cwa type, according to Köppen's classification, with hot and rainy summers and dry winters, and average annual rainfall of 1,400 $\mathrm{mm}$. During the experimental period, meteorological conditions were unfavorable to the evaluated crops, with rainfall below the historical average in December 2011, December 2012, and January 2013, and with high temperatures in the second half of 2012 (Figure 1).

The experimental design was of complete randomized blocks, with seven replicates. The cropping modalities evaluated were sole cropping and intercropping of soybean [Glycine $\max$ (L.) Merr.] with the following forages: Megathyrsus maximus (Syn. Panicum maximum), Aruana and BRS Tamani (PM45) cultivars; Urochloa brizantha (Syn. Brachiaria brizantha), Xaraés, BRS Piatã, and BRS Paiaguás cultivars; Urochloa decumbens (Syn. Brachiaria decumbens); and Urochloa ruziziensis (Syn. Brachiaria ruziziensis). The evaluations were carried out in the 2011/2012 and 2012/2013 crop years, in two different but nearby areas. The experiments were not considered as factorial, because the areas were not the same and the methodologies used in them were not exactly alike.

The forages were intercropped with the soybean cultivar most used in the south of the state of Mato Grosso do Sul - BMX Potência, which is considered tall. The used forage genotypes stood out in other experiments with sole crops, aiming their adoption in ICLS (Machado \& Assis, 2010; Machado \& Valle, 2011).

The experiments were conducted in a Latossolo Vermelho distroférrico (Santos et al., 2013) - a Rhodic Hapludox. In 2011, prior to sowing, soil chemical analysis showed: $\mathrm{pH}\left(\mathrm{H}_{2} \mathrm{O}\right)$ of 5.3; $\mathrm{pH}\left(\mathrm{CaCl}_{2}\right)$ of 4.5; 0.6, 3.2, 0.7, 8.9, and $0.7 \mathrm{cmol}_{\mathrm{c}} \mathrm{dm}^{-3} \mathrm{Al}^{3+}, \mathrm{Ca}^{2+}, \mathrm{Mg}^{2+}$, $\mathrm{H}+\mathrm{Al}$, and $\mathrm{K}^{+}$, respectively; $44.2 \mathrm{mg} \mathrm{dm}^{-3} \mathrm{P}$ (Mehlich-1); $5.2 \mathrm{cmol}_{\mathrm{c}} \mathrm{dm}^{-3}$ effective cation exchange capacity (CEC); base saturation (BS) of $34.1 \%$; and $33.9 \mathrm{~g} \mathrm{~kg}^{-1}$ soil organic matter (SOM). On 10/6/2011, 3,000 kg ha-1 dolomitic limestone with $70 \%$ effective calcium carbonate equivalent (ECCE) rating were applied on soil surface. In 2012, in the other experimental area, the chemical analysis showed: $\mathrm{pH}\left(\mathrm{H}_{2} \mathrm{O}\right)$ 5.6; $\mathrm{pH}$ $\left(\mathrm{CaCl}_{2}\right)$ 4.9; 0.1, 5.8, 2.2, 6.2, and $1.2 \mathrm{cmol}_{\mathrm{c}} \mathrm{dm}^{-3} \mathrm{Al}^{3+}$, $\mathrm{Ca}^{2+}, \mathrm{Mg}^{2+}, \mathrm{H}+\mathrm{Al}$, and $\mathrm{K}^{+}$, respectively; $24.2 \mathrm{mg} \mathrm{dm}^{-3}$ $\mathrm{P}$ (Mehlich-1); effective CEC of $9.3 \mathrm{cmol}_{\mathrm{c}} \mathrm{dm}^{-3}$; BS of $60 \%$; and $32.8 \mathrm{~g} \mathrm{~kg}^{-1} \mathrm{SOM}$.

Before soybean planting, weeds were controlled with $4.0 \mathrm{~L} \mathrm{ha}^{-1}$ glyphosate $\left(360 \mathrm{~g} \mathrm{~L}^{-1}\right.$ of the acid equivalent of N-phosphonomethyl glycine), with the addition of $0.5 \%$ mineral oil on a volume basis. Soybean seeds were treated with a carboxin- and thiram-based fungicide, and, later, Bradyrhizobium japonicum was inoculated. Soybean was planted on 10/28/2011 and 11/20/2012, under no-tillage system, using the SHM seed planter (Semeato S/A Implementos Agrícolas, Passo Fundo, RS, Brazil), at a density of 32 to 35 viable soybean seeds per square meter. At planting, $200 \mathrm{~kg} \mathrm{ha}^{-1}(2011)$ and $283 \mathrm{~kg} \mathrm{ha}^{-1}$ (2012) of $\mathrm{N}-\mathrm{P}_{2} \mathrm{O}_{5}-\mathrm{K}_{2} \mathrm{O}$ (5-30-15) fertilizer were applied into the planting furrow. In the 2011/2012 and 2012/2013 crop seasons, the plots measured $6.0 \times 6.0 \mathrm{~m}$ and $4.0 \times 5.5 \mathrm{~m}$, respectively, and row spacing was 60 and $55 \mathrm{~cm}$.

Forages were planted with a delay of 21 (2011) and 14 days (2012) after soybean emergence, using a self-propelled plot seeder (Wintersteiger AG, Ried im Innkreis, Austria). Forage seeds were planted 
in between soybean rows, at approximately $4.0-\mathrm{cm}$ depth. In 2012, $20 \mathrm{~mm}$ of water were applied with a conventional sprinkler irrigation system, in order to ensure forage emergence on the scheduled date. For the Urochloa spp. and M. maximus genotypes, seeding densities of 60 and 300 viable pure seeds per square meter, respectively, were used. Immediately after the forages were sown, weeds were controlled with the application of $3.0 \mathrm{~L} \mathrm{ha}^{-1}$ glyphosate, with the addition of $0.5 \%$ mineral oil on a volume basis. After this application at soybean preemergence, herbicides were not applied again in the experiments. In the 2012/2013 crop season, soybean and forage plants were thinned to 25 and 15 plants per square meter, respectively, in order to standardize the competition between the species and minimize the experimental error. The density of soybean plants at the time of harvest was 251-268 (2011/2012) and 145-170 (2012/2013) thousand plants per hectare.

Soybean grain yield was determined in six 2.0$\mathrm{m}$ long rows in each experimental unit, using a plot seeder (Wintersteiger AG, Ried im Innkreis, Austria), on $3 / 2 / 2012$ and $3 / 25 / 2013$. The cutter bar was set to harvest plants below the insertion of the first pods, between 10 and $15 \mathrm{~cm}$ above soil level. The following variables were determined in one of the six rows: plant height and stand, i.e., the distance from soil surface to the tip of the last extended leaf and to the top of the plant community, respectively; density of soybean, weeds, and forage plants; and number of forage tillers. Subsequently, soybean was manually harvested to determine grain yield components. In addition, a shoot sample from the other plants was collected in between the soybean rows, to determine weed and forage dry mass. The humidity of the samples was determined, and impurity was manually separated from grains to determine grain mass, adjusted to $13 \%$ moisture.

To test the normality hypothesis, residues were subjected to the Shapiro-Wilk test, and the variables that presented normal distribution were evaluated by the linear model methodology. For those that did not present a normal distribution of residues, the analyses were performed using the generalized linear model methodology, assuming a binomial distribution for the variables (\%): humidity, impurity, and empty pods. The Poisson distribution was assumed for number of grains per pod and number of weeds; and the Gama one, for weed dry mass. Then, data were subjected to the chisquare test, and the variables with normal distribution, to the analysis of variance. Means were compared by Fisher's LSD test, at 5\% probability, by using the R software (R Core Team, 2016). For the regressions, the SigmaPlot software, version 11.0 (Systat Software Inc., Chicago, IL, USA), was used.

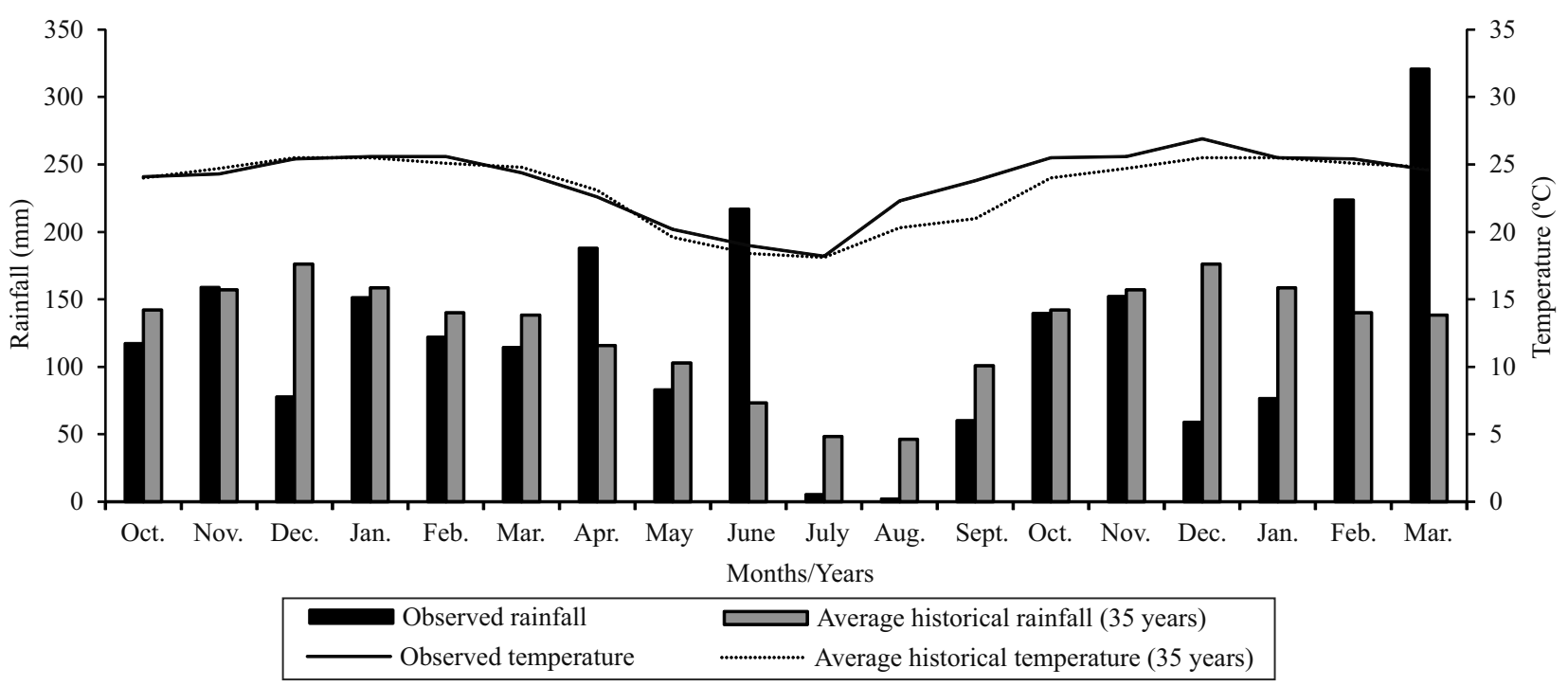

Figure 1. Monthly rainfall and temperature observed during the experimental period, from October 2011 to March 2013, and historical means recorded at the meteorological station of Embrapa Agropecuária Oeste, in the municipality of Dourados, in the state of Mato Grosso do Sul, Brazil. 


\section{Results and Discussion}

The cultivation modalities did not differ regarding grain yield (Table 1). Numerical but not significant differences were observed for this variable, similarly to what was reported in other studies with soybean intercropped with forages of the genus Urochloa spp. (Pereira et al., 2011; Mariani et al., 2012; Saraiva et al., 2013; Franchini et al., 2014).

Accepting the null hypothesis in the analysis of variance for soybean yield may be considered a conservative decision and implies admitting differences of up to $582 \mathrm{~kg} \mathrm{ha}^{-1}$ as nonsignificant (Table 1), in the 2012/2013 crop season. Supposing the null hypothesis was false, a type II error would incur and the proposed intercropping would compromise the profitability of the activity, especially when the production cost is close to that of the gross revenue, as predicted for the 2015/2016 crop season (Richetti, 2015). By accepting $10 \%$ significance for the test of means, the analysis becomes more permissive, which, in the present study, penalized the alternative modalities that represent a greater risk to soybean grain yield. However, in this degree of significance, the average grain yield was greater only for sole soybean, compared with the intercropping with $U$. ruziziensis and 'BRS Piatã', in the 2012/2013 crop season.

When evaluating soybean intercropped with $U$. brizantha, Duarte et al. (1995) found a reduction in the grain yield of the oilseed, which was not observed with $U$. humidicola. The first forage presents a bunch/ erect growth habit, which favors the competition with soybean for light; the second one is stoloniferous and hardly reaches the top of the canopy, being less competitive. In the present study, the morphological characteristics of the forages may have favored soybean when intercropped with 'BRS Tamani', which has a short stem, and with 'BRS Paiaguás' and 'Aruana', which have thin culms that are susceptible to easy lodging. Plants with this characteristic have disadvantages when competing with soybean, unlike what was observed for U. ruziziensis, which has thicker and longer stems.

The average percentage of impurities in soybean grains was higher for the intercropping with $U$. ruziziensis (Table 1) and lower for the one with 'Xaraés', in 2011/2012, and for sole cropping, in $2012 / 2013$. Grain humidity was lower in the sole

Table 1. Soybean (Glycine max) yield components when in sole crop or intercropped with tropical forages, in the 2011/2012 and 2012/2013 crop seasons ${ }^{(1)}$.

\begin{tabular}{|c|c|c|c|c|c|c|c|}
\hline Crop & $\begin{array}{l}\text { Grain yield } \\
\left(\mathrm{kg} \mathrm{ha}^{-1}\right)\end{array}$ & $\begin{array}{c}\text { Grain impurity } \\
(\%)\end{array}$ & $\begin{array}{c}\text { Grain humidity } \\
(\%)\end{array}$ & $\begin{array}{c}\text { No. of pods } \\
\text { per plants }\end{array}$ & $\begin{array}{c}\text { Pods without } \\
\text { grains (\%) }\end{array}$ & $\begin{array}{c}\text { No. of grains } \\
\text { per pods }\end{array}$ & $\begin{array}{l}\text { 100-grain } \\
\text { weight }(\mathrm{g})\end{array}$ \\
\hline & \multicolumn{7}{|c|}{ 2011/2012 crop season } \\
\hline Soybean (sole crop) & 1,782 & $1.0 \mathrm{ab}$ & $9.5 b$ & $38.9 \mathrm{a}$ & $3.2 b$ & $1.8 \mathrm{c}$ & 10.1 \\
\hline Soybean+Aruana & 1,867 & $0.9 \mathrm{bc}$ & $9.8 \mathrm{a}$ & $37.7 \mathrm{ab}$ & $3.1 \mathrm{~b}$ & $2.0 \mathrm{~b}$ & 10.2 \\
\hline Soybean+BRS Tamani & 2,111 & $0.9 \mathrm{bc}$ & $9.8 \mathrm{a}$ & $39.2 \mathrm{a}$ & $1.8 \mathrm{c}$ & $1.9 \mathrm{~b}$ & 10.3 \\
\hline Soybean + Xaraés & 1,905 & $0.8 \mathrm{c}$ & $9.8 \mathrm{a}$ & $29.8 \mathrm{c}$ & $4.8 \mathrm{a}$ & $2.0 \mathrm{ab}$ & 10.5 \\
\hline Soybean+BRS Piatã & 1,829 & $1.0 \mathrm{ab}$ & $9.8 \mathrm{a}$ & $35.5 \mathrm{~b}$ & $3.7 \mathrm{ab}$ & $1.9 \mathrm{~b}$ & 10.1 \\
\hline Soybean+BRS Paiaguás & 1,850 & $0.9 \mathrm{bc}$ & $9.7 \mathrm{a}$ & $38.6 \mathrm{a}$ & $3.8 \mathrm{ab}$ & $1.3 \mathrm{~d}$ & 10.1 \\
\hline Soybean+Urochloa decumbens & 1,662 & $0.9 \mathrm{bc}$ & $9.8 \mathrm{a}$ & $39.4 \mathrm{a}$ & $3.4 \mathrm{ab}$ & $1.7 \mathrm{c}$ & 10.1 \\
\hline Soybean+Urochloa ruziziensis & 1,774 & $1.1 \mathrm{a}$ & $9.8 \mathrm{a}$ & $37.3 \mathrm{ab}$ & $4.6 \mathrm{a}$ & $2.1 \mathrm{a}$ & 9.6 \\
\hline \multirow[t]{2}{*}{ Coefficient of variation $(\%)$} & 15.3 & 45.5 & 2.5 & 15.8 & 47.8 & 15.7 & 5.0 \\
\hline & \multicolumn{7}{|c|}{$2012 / 2013$ crop season } \\
\hline Soybean (sole crop) & $2,199 \mathrm{a}$ & $6.0 \mathrm{c}$ & $14.3 \mathrm{e}$ & $53.6 \mathrm{ab}$ & - & 2.2 & 12.1 \\
\hline Soybean+Aruana & $2,019 \mathrm{ab}$ & $7.7 \mathrm{~b}$ & $15.3 \mathrm{bcd}$ & $56.9 \mathrm{a}$ & - & 1.5 & 12.4 \\
\hline Soybean+BRS Tamani & $2,010 \mathrm{ab}$ & $7.8 \mathrm{~b}$ & $16.3 \mathrm{ab}$ & $55.7 \mathrm{a}$ & - & 2.1 & 12.2 \\
\hline Soybean + Xaraés & $2,005 \mathrm{ab}$ & $7.8 \mathrm{~b}$ & 14.6de & $52.3 \mathrm{ab}$ & - & 1.7 & 12.5 \\
\hline Soybean+BRS Piatã & $1,818 \mathrm{bc}$ & $8.5 \mathrm{ab}$ & $15.8 \mathrm{abc}$ & $47.1 \mathrm{bc}$ & - & 2.2 & 12.5 \\
\hline Soybean+BRS Paiaguás & $2,063 \mathrm{ab}$ & $7.4 \mathrm{bc}$ & $15.4 \mathrm{bcd}$ & $45.0 \mathrm{c}$ & - & 2.2 & 12.7 \\
\hline Soybean + Urochloa decumbens & $2,012 \mathrm{ab}$ & $8.1 \mathrm{~b}$ & 15.1cde & $49.8 \mathrm{abc}$ & - & 1.7 & 12.4 \\
\hline Soybean + Urochloa ruziziensis & $1,617 \mathrm{c}$ & $10.3 \mathrm{a}$ & $16.5 \mathrm{a}$ & $47.1 \mathrm{bc}$ & - & 2.0 & 12.4 \\
\hline Coefficient of variation (\%) & 16.8 & 2.9 & 0.2 & 19.2 & - & 27.8 & 3.3 \\
\hline
\end{tabular}


soybean crop, when compared with the other cropping modalities, in 2011/2012; and, in 2012/2013, it only did not differ from the intercroppings soybean + 'Xaraés' and soybean $+U$. Decumbens. Grain humidity was affected by the percentage of grain impurity, mainly because it was determined without the removal of this fraction. Although this procedure is not usual, it allows inferring the potential of impurity interfering in grain moisture. In addition, when there is high forage mass, a microclimate is created, which makes it difficult to dissipate humidity into the canopy. These aspects may have affected grain quality.

The modalities with the highest average number of pods per plant were: sole soybean crop, soybean + 'BRS Tamani', soybean + 'BRS Paiaguás', and soybean + U. ruziziensis, in 2011/2012; and soybean + 'Aruana' and soybean + 'BRS Tamani', in 2012/2013. The lowest values were observed with: soybean + 'Xaraés', in 2011/2012, and soybean + 'BRS Paiaguás', in $2012 / 2013$. Only in $2011 / 2012$, pods without grains were observed, and soybean $+U$. ruziziensis showed the highest percentage (Table 1).

There were differences in the average number of grains per pod only in the 2011/2012 crop season, with the highest values obtained for the soybean + $U$. ruziziensis intercropping, and the lowest ones for soybean + 'BRS Paiaguás' (Table 1). In the 2012/2013 crop season, no differences were observed between treatments for the average number of grains per pod and 100 -grain weight.

Although several studies on intercropping focus on the possibility of competition between forages and soybean, there are no reports on changes in the grain yield components of the oilseed when intercropped with grasses (Mariani et al., 2012; Saraiva et al., 2013; Crusciol et al., 2014; Franchini et al., 2014). Significant differences, however, were found by Crusciol et al. (2012) and Saraiva et al. (2014), who observed reduction in the number of pods per plant and of grains per pod in the soybean $+U$. brizantha intercropping. In the present study, the sole soybean crop showed a greater number of pods per plant than the intercropping with 'Xaraés' and 'Piatã', in 2011/2012, and with 'BRS Paiaguás', in 2012/2013.

The correct management of the forage can change its competitive ability with soybean. Silva et al. (2005a) reported a reduction in yield components when the forage was planted in advance, simultaneously or with a delay of less than 14 days after soybean emergence. The delayed planting of the forage, besides reducing the potential forage competition, allows the application of herbicides for weed control before soybean emergence. If the grass develops more than expected, its growth can also be inhibited by applying herbicides (Cobucci \& Portela, 2003; Silva et al., 2004).

For the average height of the soybean plants, no differences were found between the cultivation modalities, in the two crop years (Table 2). Studies conducted by Crusciol et al. $(2012,2014)$ and Franchini et al. (2014) showed changes in this variable between years or among genotypes. The average insertion height of the first pods ranged from 12.5 to $14.5 \mathrm{~cm}$; however, no differences were observed between cultivation modalities, which is in alignment with Franchini et al. (2014) and Crusciol et al. (2014), but differs from Silva et al. (2004) and Crusciol et al. (2012). The average height of plants and of the insertion of the first pods are characteristics that vary between soybean genotypes and present some plasticity in relation to environmental changes (Crusciol et al., 2012; Franchini et al., 2014). Soybean cultivars larger in size and with a higher pod insertion height may be more competitive for light and, therefore, less susceptible to competition with forages and to the grain depreciation caused by impurity, at harvest time.

The height of the forage plants also did not differ between cultivation modalities (Table 2); the highest numerical value was obtained with $U$. decumbens, in 2011/2012, and the lowest with $U$. ruziziensis, 2011/2012 and 2012/2013.

In the 2012/2013 crop season, although thinning was done to standardize the density of forage plants, this number decreased at harvest. The lowest density of forage plants was found in the soybean $+U$. ruziziensis intercropping (Table 2). The reduction in the number of plants during the soybean cycle may be associated with the shading caused by the crop. According to Kluthcouski \& Aidar (2003) and Zimmer et al. (1987), 6 to 20 plants per square meter are required for the establishment of pastures, a criterion met in the present study. 'BRS Tamani' presented the highest number of tillers. In stress conditions, when an herbicide is applied to control forage growth in intercropping, many tillers senescence and die (Silva et al., 2005b); therefore, a high density of both plants and tillers is essential to ensure pasture formation. 
The number of weeds was higher with sole soybean crop and soybean + 'BRS Piatã ' in the 2011/2012 crop season, and with soybean + 'Xaraés' in 2012/2013. The presence of forages may have contributed to a reduction in the number and, in particular, in the dry matter of weeds, from $181 \mathrm{~kg} \mathrm{ha}^{-1}$, in the sole soybean crop, to 20 to $76 \mathrm{~kg} \mathrm{ha}^{-1}$, in the intercrop (Table 2). This result can be attributed to the increased competition for resources such as light, water, and nutrients, or even to the allelopathic effect of forages (Lithourgidis et al., 2011). These values are well below those reported by Ikeda (2010) for soybean without weeding, but similar to those with weeding. The lowest value obtained was certainly related to the chemical control after soybean sowing, due to the delayed planting of the forages.

The dry matter yield of the forages was in alignment with the one reported by Mariani et al. (2012) for the 'Aruana' and 'Mombaça' grasses intercropped with soybean; however, it was much lower than the 3,058 $\mathrm{kg} \mathrm{ha}^{-1}$ obtained by the authors in the intercropping with 'Marandu' grass. The discrepancy in these results may be related to the simultaneous planting of the forages and soybean, differently from what was done in the present study, in which the forage was planted after soybean. Mata et al. (2011), in turn, obtained significantly lower values for this variable, probably because of the narrower spacing adopted between soybean rows $(40 \mathrm{~cm})$ and of the longer planting interval (20 to 30 days after the oilseed), which favored the growth of the soybean crop in detriment of the forage.
For the dry matter of forage + weeds, Silva et al. (2006) found values much higher than those obtained in the present study, which may also be related to the simultaneous planting of the forage employed by the authors.

Soybean grain yield showed a negative linear response to the increase in dry matter of forage + weeds, in the intercropping with the 'Aruana', 'BRS Tamani', 'BRS Paiaguás', and U. ruziziensis grasses (Figure 2). The increase of each kilogram in the mass of forage + weeds was responsible for the reduction of 0.412 to $0.994 \mathrm{~kg} \mathrm{ha}^{-1}$ soybean grains. Although the dry matter of forage + weeds in soybean intercropped with 'BRS Tamani' grass did not differ from that of soybean $+U$. ruziziensis, with values close to $1,500 \mathrm{~kg} \mathrm{ha}^{-1}$, the average grain yield of the oilseed was higher in the first intercropping (Tables 1 and 2).

Herbicides may be applied post-emergence to reduce the competition between forages and soybean, and their application in dry season is also common at the end of the soybean cycle, to facilitate mechanical harvesting (Cobucci \& Portela, 2003; Kluthcouski $\&$ Aidar, 2003). However, these measures were not adopted in the present study because they implied in risks to forage survival (Silva et al., 2006), besides being another source of variation without an adequate control, since the tolerance of the genotypes to the herbicides is not the same (Machado \& Assis, 2010; Machado \& Valle, 2011).

The damage to soybean yield is related to the competition for limited resources such as water, light,

Table 2. Yield and morphological components of soybean (Glycine max), tropical forages, and weeds, in the $2011 / 2012$ and $2012 / 2013$ crop seasons, in sole soybean crop or intercrop with tropical forages ${ }^{(1)}$.

\begin{tabular}{|c|c|c|c|c|c|c|c|c|c|c|c|c|c|}
\hline \multirow[t]{3}{*}{ Crop } & \multicolumn{3}{|c|}{ Soybean $^{(2)}$} & \multicolumn{6}{|c|}{ Forage $^{(3)}$} & \multicolumn{4}{|c|}{ Weed $^{(4)}$} \\
\hline & \multicolumn{2}{|c|}{ Plant height $(\mathrm{cm})$} & \multirow{2}{*}{$\begin{array}{l}\text { HFL } \\
2013 \\
\end{array}$} & \multicolumn{2}{|c|}{ Plant stand $(\mathrm{cm})$} & \multicolumn{2}{|c|}{$\mathrm{NPH}$} & \multirow{2}{*}{$\frac{\text { NTSM }}{2012 / 13}$} & \multirow{2}{*}{$\frac{F}{2011 / 12}$} & \multicolumn{2}{|c|}{ NPSQ } & \multirow{2}{*}{$\begin{array}{c}\text { W } \\
2012 / 13\end{array}$} & \multirow{2}{*}{$\begin{array}{c}\mathrm{F}+\mathrm{W}^{(5)} \\
2012 / 13\end{array}$} \\
\hline & 2012 & 2013 & & 2012 & 2013 & $2011 / 12$ & $2012 / 13$ & & & $2011 / 12$ & $2012 / 13$ & & \\
\hline oybean (sole crop) & 101.2 & 88.1 & 12.5 & - & - & - & - & - & - & $0.8 \mathrm{a}$ & $8.8 \mathrm{~b}$ & $181 \mathrm{a}$ & $181 \mathrm{~b}$ \\
\hline Soybean+Aruana & 101.2 & 86.7 & 13.0 & 29.6 & 69.0 & $56.6 \mathrm{ab}$ & $14.3 \mathrm{a}$ & $205 b$ & $853 \mathrm{c}$ & $0.3 \mathrm{c}$ & $5.6 \mathrm{~d}$ & 26de & $879 \mathrm{ab}$ \\
\hline Soybean+BRS Tamani & 100.9 & 84.6 & 13.3 & 30.9 & 77.6 & $35.2 \mathrm{~cd}$ & $14.4 \mathrm{a}$ & $286 \mathrm{a}$ & $1,524 \mathrm{a}$ & $0.5 \mathrm{~b}$ & $8.6 \mathrm{bc}$ & $34 \mathrm{cde}$ & $1,558 \mathrm{a}$ \\
\hline Soybean+Xaraés & 100.0 & 86.6 & 12.8 & 40.3 & 67.6 & $22.0 \mathrm{de}$ & $12.6 \mathrm{ab}$ & $133 \mathrm{c}$ & $822 \mathrm{c}$ & $0.7 \mathrm{ab}$ & $13.8 \mathrm{a}$ & $42 \mathrm{bcde}$ & $864 \mathrm{ab}$ \\
\hline Soybean+BRS Piatã & 102.9 & 86.6 & 14.5 & 34.7 & 81.9 & $27.3 \mathrm{cde}$ & $12.9 \mathrm{ab}$ & $127 \mathrm{c}$ & $1,283 \mathrm{abc}$ & $0.8 \mathrm{a}$ & $9.6 \mathrm{ab}$ & $51 \mathrm{bcd}$ & $1,335 \mathrm{abc}$ \\
\hline Soybean+BRS Paiaguás & 103.5 & 86.3 & 14.3 & 33.6 & 67.3 & $43.5 \mathrm{bc}$ & $11.9 \mathrm{ab}$ & $172 \mathrm{bc}$ & $915 b c$ & $0.7 \mathrm{ab}$ & $8.8 \mathrm{~b}$ & $76 \mathrm{ab}$ & $991 b c$ \\
\hline Soybean $+U$. decumbens & 100.5 & 88.2 & 13.5 & 35.7 & 67.0 & $64.0 \mathrm{a}$ & $12.5 \mathrm{ab}$ & $177 \mathrm{bc}$ & $826 \mathrm{c}$ & $0.2 \mathrm{~d}$ & $7.9 \mathrm{bcd}$ & $66 \mathrm{bc}$ & $893 \mathrm{ab}$ \\
\hline Soybean $+U$. ruziziensis & 100.9 & 85.7 & 14.3 & 32.1 & 74.7 & $16.1 \mathrm{e}$ & $10.0 \mathrm{~b}$ & $161 \mathrm{bc}$ & $1,409 \mathrm{ab}$ & $0.6 \mathrm{ab}$ & $5.7 \mathrm{~cd}$ & $20 \mathrm{e}$ & $1,429 \mathrm{ab}$ \\
\hline
\end{tabular}

${ }^{(1)}$ Means followed by equal letters, in the columns, do not differ significantly by Fisher's LSD test, at $5 \%$ probability. ${ }^{(2)} \mathrm{HFL}$, height of first pod (cm). ${ }^{(3)} \mathrm{NPH}$, number of plants per hectare; NTSM, number of tillers per square meter; and F, dry matter of forage $\left(\mathrm{kg} \mathrm{ha}^{-1}\right) .{ }^{(4)} \mathrm{NPSQ}$, number of plants per square meter; and $\mathrm{W}$, dry matter of weeds $\left(\mathrm{kg} \mathrm{ha}^{-1}\right) \cdot{ }^{(5)} \mathrm{F}+\mathrm{W}$, dry matter of forages added to that of weeds. 
and nutrients. At simultaneous planting, there is an increase in the forage growth rate from 50 days after emergence (DAE). If, for this stage, no herbicide intervention is performed, the forage can reach the top of the canopy at approximately $80 \mathrm{DAE}$ and compete for light, with a significant effect on the grain yield of the annual crop (Cobucci \& Portela, 2003). Since, in the present work, the average height of soybean far exceeded the average stand of the forage, the possibility of the grasses competing with soybean for light was discarded (Table 2).

Grain yields lower than expected may be related to the water deficit observed in the crop years, with rainfall below the historical average in some periods, especially in the 2011/2012 crop year. In intercropped crops, there is an increase in plant density and leaf area, which results in increased evapotranspiration and water demand, potentiating the effect of water deficit (Allen et al., 2006; Souza et al., 2012). Morphological differences and forage extraction capacity may have contributed to water competition between grasses and soybean. The fasciculate root system of forages allows them to explore a larger volume of soil and gives them a greater water-extraction capacity than a plant with a pivotal root, such as soybean. In addition, the greatest effective depth of the root system of forage plants -1.0 to $1.5 \mathrm{~m}$ in comparison with 0.6 to $1.3 \mathrm{~m}$ for soybean - and the higher depletion factor of water availability -
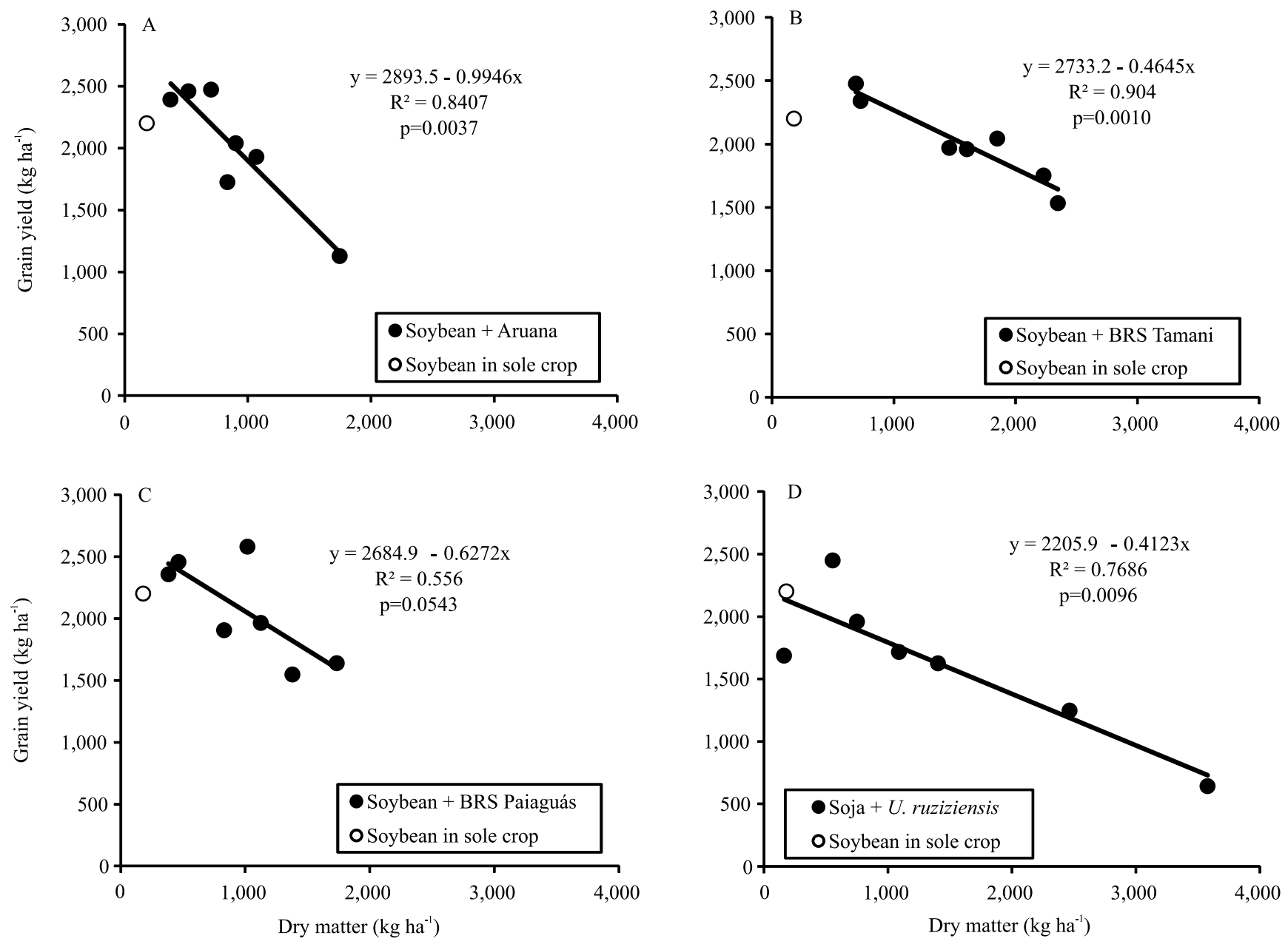

Figure 2. Soybean (Glycine max) grain yield as a function of weeds + forage dry matter mass, in sole crop or intercropped with the following tropical forages in 2012/2013: A, 'Aruana'; B, 'BRS Tamani'; C, 'BRS Paiaguás'; and D, Urochloa ruziziensis. 
55 to $60 \%$ compared with soybean, with $\sim 50 \%$ (Allen et al., 2006) - contribute to this result.

The application of herbicide dosages was indicated for intercropping with 'MG5' and 'Aruana' (Silva et al., 2004; Concenco et al., 2014) when the forage was competitive with soybean, with simultaneous planting. However, since herbicide tolerance varies among forages, it is necessary to study products and adjust doses to control the growth of the grass, so that the production of soybean is not compromised.

Some favorable characteristics of the forages to intercropping are worth mentioning, such as the presence of short stalks in 'BRS Tamani' and of thin stems in 'BRS Paiaguás', which facilitates lodging. Plants with these characteristics may present lower competition ability for light, reducing the risk of damages to soybean grain yield.

\section{Conclusions}

1. The establishment of perennial forages of the species Megathyrsus maximus, Aruana and BRS Tamani cultivars; Urochloa brizantha, Xaraés, BRS Piatã, and BRS Paiaguás cultivars; U. decumbens; and $U$. ruziziensis in intercropping with soybean (Glycine max) may be viable with delayed planting in relation to the emergence of the oilseed.

2. 'BRS Tamani' is the best suited for intercropping with soybean, considering its morphological characteristics and low competition ability.

3. The intercropping of soybean and perennial forages contributes to suppress weed growth.

\section{References}

ALLEN, R.G.; PEREIRA, L.S.; RAES, D.; SMITH, M. Evapotranspiración del cultivo: guías para la determinación de los requerimientos de agua de los cultivos. Rome: FAO, 2006. 298p. (Estudio FAO Riego y Drenaje, 56).

CAMPOS, K.C. Análise da volatilidade de preços de produtos agropecuários no Brasil. Revista de Economia e Agronegócio, v.5, p.303-328, 2007.

COBUCCI, T.; PORTELA, C.M. de O. Manejo de herbicidas no Sistema Santa Fé e na braquiária como fonte de cobertura morta. In: KLUTHCOUSKI, J.; STONE, L.F.; AIDAR, H. (Ed.). Integração lavoura-pecuária. Santo Antônio de Goiás: Embrapa Arroz e Feijão, 2003. p.443-458.

CONCENCO, G.; MACHADO, L.A.Z.; GALON, L.; CORREIA, I.V.T.; SANTOS, S.A. dos; PALHARINI, W.G. Supressão química do crescimento de Panicum maximum cv. aruana cultivado em consórcio com a cultura da soja. Agrarian, v.7, p.176-188, 2014.
CRUSCIOL, C.A.C.; MATEUS, G.P., NASCENTE, A.S.; MARTINS, P.O.; BORGHI, E.; PARIZ, C.M. An innovative crop-forage intercrop system: early cycle soybean cultivars and palisadegrass. Agronomy Journal, v.104, p.1085-1095, 2012. DOI: 10.2134/agronj2012.0002.

CRUSCIOL, C.A.C.; NASCENTE, A.S.; MATEUS, G.P.; PARIZ, C.M.; MARTINS, P.O.; BORGHI, E. Intercropping soybean and palisade grass for enhanced land use efficiency and revenue in a no till system. European Journal of Agronomy, v.58, p.53-62, 2014. DOI: 10.1016/j.eja.2014.05.001.

DUARTE, J.M.; PÉREZ, H.E.; PEZO, D.A.; ARZE, J.; ROMERO, F.; ARGEL, P.J. Producción de maíz (Zea mays L.), soya (Glycine max L.) y caupí (Vigna unguiculata (L.) Walp) sembrados en asociación con gramíneas en el trópico húmedo. Pasturas Tropicales, v.17, p.12-19, 1995.

FRANCHINI, J.C.; BALBINOT JUNIOR, A.A.; DEBIASI, H.; PROCÓPIO, S. de O. Intercropping of soybean cultivars with Urochloa. Pesquisa Agropecuária Tropical, v.44, p.119-126, 2014. DOI: $10.1590 /$ S1983-40632014000200007.

IKEDA, F.S. Interação entre as culturas de soja e milho com cultivares do gênero Urochloa $P$. Beauv. em consórcio e interferência de plantas daninhas nos sistemas. 2010. 162p. Tese (Doutorado) - Universidade de São Paulo, Escola Superior de Agricultura "Luiz de Queiroz", Piracicaba. DOI: 10.11606/T.11.2010.tde-09022011-162325.

KLUTHCOUSKI, J.; AIDAR, H. Implantação, condução e resultados obtidos com o Sistema Santa Fé. In: KLUTHCOUSKI, J.; STONE, L.F.; AIDAR, H. (Ed.). Integração lavoura-pecuária. Santo Antônio de Goiás: Embrapa Arroz e Feijão, 2003. p.407442.

LITHOURGIDIS, A.S.; DORDAS, C.A.; DAMALAS, C.A.; VLACHOSTERGIOS, D.N. Annual intercrops: an alternative pathway for sustainable agriculture. Australian Journal of Crop Science, v.5, p.396-410, 2011.

MACHADO, L.A.Z.; ASSIS, P.G.G. de. Produção de palha e forragem por espécies anuais e perenes em sucessão à soja. Pesquisa Agropecuária Brasileira, v.45, p.415-422, 2010. DOI: 10.1590/S0100-204X2010000400010.

MACHADO, L.A.Z.; VALLE, C.B. do. Desempenho agronômico de genótipos de capim-braquiária em sucessão à soja. Pesquisa Agropecuária Brasileira, v.46, p.1454-1462, 2011. DOI: 10.1590/ S0100-204X2011001100006.

MARIANI, F.; FONTANELI, R.S.; VARGAS, L.; SANTOS, H.P. dos; FONTANELI, R.S. Estabelecimento de gramíneas forrageiras tropicais perenes simultaneamente com as culturas de milho e soja no Norte do RS. Ciência Rural, v.42, p.1471-1476, 2012. DOI: $10.1590 / \mathrm{S} 0103-84782012000800023$.

MATA, J.F.; ERASMO, E.A.L.; SIEBENEICHLER, S.C.; SARAIVA, A. de S.; GONÇALVES, R.C. Análise de crescimento da Brachiária em diferentes densidades e épocas de semeadura em consorcio com a cultura da soja. Pesquisa Aplicada e Agrotecnologia, v.4, p.7-30, 2011. DOI: 10.5777/paet.v4.n3.01.

PEREIRA, R.G.; ALBUQUERQUE, A.W. de; SOUZA, R. de O.; SILVA, A.D. da; SANTOS, J.P.A. dos; BARROS, E. da S.; MEDEIROS, P.V.Q. de. Sistemas de manejo do solo: soja [Glycine 
max (L.)] consorciada com Brachiaria decumbens (STAPF). Pesquisa Agropecuária Tropical, v.41, p.44-51, 2011. DOI: 10.5216/pat.v41i1.6981.

PINTO, H.S.; AVILA, A.M.H. de; CARDOSO, A. O. Challenges to increased soybean production in Brazil. In: BOARD, J.E. (Ed.). A comprehensive survey of international soybean research genetics, physiology, agronomy and nitrogen relationships. Rijeka: InTech, 2013. DOI: 10.5772/52647.

R CORE TEAM. R: a language and environment for statistical computing. Vienna: R Foundation for Statistical Computing, 2016. Available at: <http://r-project.org>. Accessed on: Aug. 302016.

RICHETTI, A. Viabilidade econômica da cultura da soja na safra 2015/2016, em Mato do Grosso do Sul. Dourados: Embrapa Agropecuária Oeste, 2015. 13p. (Embrapa Agropecuária Oeste. Comunicado técnico, 202).

SANTOS, H.G. dos; JACOMINE, P.K.T.; ANJOS, L.H.C. dos; OLIVEIRA, V.A. de; LUMBRERAS, J.F.; COELHO, M.R.; ALMEIDA, J.A. de; CUNHA, T.J.F.; OLIVEIRA, J.B. de. Sistema brasileiro de classificação de solos. 3.ed. rev. e ampl. Brasília: Embrapa, 2013. 353p.

SARAIVA, A.S.; DORNELAS, B.F.; SILVA, J.I.C.; ERASMO, E.A.L.; DORNELAS, D.F.; MATA, J.F.; SARMENTO, R.A. Soja M-8527 RR consorciada com braquiária piatã em diferentes densidades e épocas de semeadura. Planta Daninha, v.32, p.497505, 2014. DOI: 10.1590/S0100-83582014000300005.

SARAIVA, A.S.; ERASMO, E.A.L.; MATA, J.F.; DORNELAS, B.F.; DORNELAS, D.F.; SILVA, J.I.C. Density and sowing season of two Brachiaria species on the soybean culture. Planta Daninha, v.31, p.569-576, 2013. DOI: 10.1590/S0100-83582013000300009.

SILVA, A.C. da; FREITAS, F.C.; FERREIRA, L.R.; FREITAS, R.S. Dessecação pré-colheita de soja e Brachiaria brizantha consorciadas com doses reduzidas de graminicida. Pesquisa Agropecuária Brasileira, v.41, p.37-42, 2006. DOI: 10.1590/ S0100-204X2006000100006.

SILVA, A.C.; FERREIRA, L.R.; SILVA, A.A. da; FREITAS, R.S.; MAURO, A. Épocas de emergência de Brachiaria brizantha no desenvolvimento da cultura da soja. Ciência Rural, v.35, p.769-775, 2005a. DOI: 10.1590/S0103-84782005000400003.

SILVA, A.C.; FERREIRA, L.R.; SILVA, A.A.; PAIVA, T.W.B.; SEDIYAMA, C.S. Efeitos de doses reduzidas de FluazifopP-Butil no consórcio entre soja e Brachiaria brizantha. Planta Daninha, v.22, p.429-435, 2004.

SILVA, A.C.; FERREIRA; L.R.; SILVA, A.A. da; BELO, A.F.; SEDIYAMA, C.S. Caracteres morfológicos de soja e braquiária consorciadas sob subdoses de fluazifop-p-butil. Ciência Rural, v.35, p.277-283, 2005b. DOI: 10.1590/S0103-84782005000200005.

SOUZA, A.P. de; LIMA, M.E. de; CARVALHO, D.F. de. Evapotranspiração e coeficientes de cultura do milho em monocultivo e em consórcio com a mucuna-cinza, usando lisímetros de pesagem. Revista Brasileira de Ciências Agrárias, v.7, p.142-149, 2012. DOI: 10.5039/agraria.v7ila802.

VILELA, L.; MARTHA JÚNIOR, G.B.; MACEDO, M.C.M.; MARCHÃO, R.L.; GUIMARÃES JÚNIOR, R.; PULROLNIK, K.; MACIEL, G.A. Sistema de integração lavoura-pecuária na região do Cerrado. Pesquisa Agropecuária Brasileira, v.46, p.1127-1138, 2011. DOI: 10.1590/S0100-204X2011001000003.

ZIMMER, A.H.; PIMENTEL, D.M.; VALLE, C.B. do; SEIFFERT, N.F. Aspectos práticos ligados a formação de pastagens. 2.reimp. Campo Grande: EMBRAPA-CNPGC, 1987. 42p. (EMBRAPA-CNPGC. Circular técnica, 12). Available at: $<$ http://docsagencia.cnptia.embrapa.br/bovinodecorte/ct/ct12/ ct12.pdf>. Accessed on: Oct. 222015.

Received on March 4, 2016 and accepted on August 30, 2016

Pesq. agropec. bras., Brasília, v.52, n.7, p.521-529, jul. 2017 DOI: $10.1590 / \mathrm{S} 0100-204 X 2017000700006$ 